\title{
FACTORS INFLUENCING THE INTENTION OF STATE FOUNDATION LOAN RECIPIENTS TO PAYBACK THE EDUCATION LOAN
}

\author{
Nurul Farhanah Mohd Idres ${ }^{1,{ }^{*},}$, Hasnah Haron ${ }^{1}$, and Ishak Ismail ${ }^{1}$ \\ ${ }^{1}$ Faculty of Industrial Management, Universiti Malaysia Pahang, Malaysia
}

ABSTRACT - The issues of loan repayment are still existing until today. One of the state foundations has reported the number of recipients that has not paid their loan are higher than the recipient who has done the repayment. Therefore, the main objective of this study is focusing on the factors that influences the recipient to pay back the loan. 48 questionnaires were distributed to the state foundation's loan recipients and a small interview were also conducted. Findings showed that the respondents had the intention to repay their loan as they were aware of their responsibilities especially the recipient that have high integrity. However, the inability to secure a good paying job is one of the reasons why they are not able to do so. Parental influence was found to be significant in influencing the loan recipients to repay their loan. It is suggested that the state foundation should increase the sense of responsibility among loan recipients to pay their loan and reminders should be given to their parents in order to convince their children to repay the loan.

ARTICLE HISTORY

Received: $17-03-2019$

Accepted: 25-05-2019

\section{KEYWORDS}

Education loan repayment, Theory of reasoning action, Integrity, Attitude, Parental Influence, Repayment

Intention

\section{INTRODUCTION}

The organization performance has been recognized as a key influence on investment decisions and becomes one of the indicators for management performance (Naser \& Mokhtar, 2004). It is also used as a measure to reflect the efficiency and effectiveness of management in the allocation of resources, ultimately aimed at maintaining sustainable organizational performance (Teoh, 2009). Undoubtedly, the absolute goal of all existing organizations is to sustain for a long time period and able to provide their enhanced products and services across time. One of the critical key factors that will ensure the organization to sustain over a long period is its financial performance. The organization either public or private sector practices different types of the performance management system to ensure the objectives are met. However, public sector organizations may face higher difficulties in sustaining their financial performance. This is because citizens often take the government funds for granted especially in terms of paying back the loan obtained from the government.

\section{PROBLEM STATEMENT}

State Foundation is one of the state statutory body that serves as the foundation to further the advancement of education, sports, culture and expand opportunities for education among citizens in the one of the east coast regions. This State Foundation aims to be the organization that is a catalyst for the development of world-class human capital which is important for the success of Vision 2020. This foundation also gives absolute focus on the educational development of their youth. They provide the complete educational package to the residence from primary school to secondary school, higher education institutions, working adults and the group of minorities.

The educational fund program by State Foundation covers all level of education at a recognized public or private HEI for a certificate, diploma, advanced diploma, degree, master and Ph.D. It is advertised in the newspaper and the official website twice a year This state foundation also covers degree studies at the Middle East.

There are two most important units that oversee educational assistance. First is the educational loan unit and second is the repayment collection unit. The following figure 1.0 shows the overall process flow of the disbursement process by the loan educational unit while figure 2.0 shows the process followed by loan repayment collection unit 


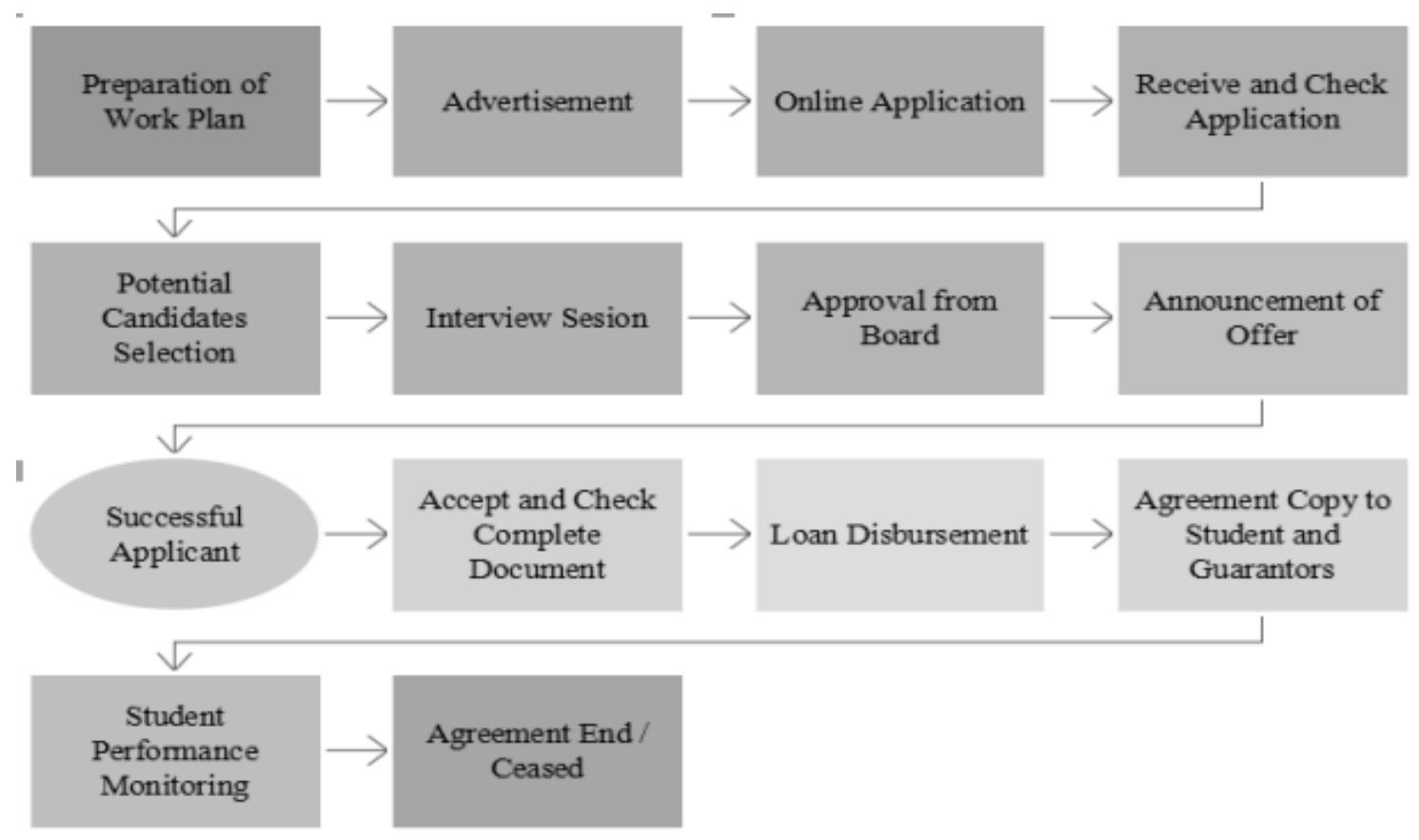

Source: Pahang State Foundation Disbursement Unit (2018)

Figure 1: Process Flow of Disbursement Process

\section{Notice of Demand}

- After six months from the end of agreement period

\section{Reminder Letter}

- If loan recipients loan repayment overdue for three months or amount overdue RM300

\section{Legal Action Notice}

- One month after reminder letter is issued

\section{Summon \& Judiciary}

- One month after legal action notice is issued

\section{Implementation Action}

- Three months after the summon/judiciary is issued

- Two actions taken either bankruptcy / foreclosure or judgement debtor summon (JDS).

Source: Pahang State Foundation Collection Unit (2018)

Figure 2: Overall Process Flow of the Collection Unit

However, an issue loan repayment keeps increasing year by year. As number of borrowers are increased, the concerns regarding students' ability to repay their loans have also increased. This area has received research attention in the last 30 years. Educational institutions around the world are presently struggling to cope with the growing problem of education debt. With this in mind, the present on-going recession and tight job market is making matters worse for students who have taken out loans and who are now unable to repay them (Dillon \& Smiles, 2010). According to Sarah \& Rich (2018), 1 in 5 federal student loan borrowers (more than 8 million Americans) are in default, and millions more are struggling to make payments. US Federal and state officials from both major political parties, researchers, advocates, and student loan servicer acknowledge that the repayment and servicing systems have serious problems. While in Malaysia, Perak State Government in debt of 17.5 million for education loan. As mention by Datuk Dr Muhammad Amin Zakaria (2017), 
Chairman of education, science, environment and Green \& Technology of state government about 4632 recipients are failed to pay back the loan and out of 20 recipients have been taken the court action. Thus, this study will identify the factors on the intention of the recipient to pay back the loan as stated in the research objective bellows:

1. To examine the level of integrity towards attitude of loan repayment.

2. To determine relationship between attitude of loan repayment focusing on integrity towards intention to repay loan.

3. To determine the relationship parental influence towards intention to repay loan

\section{LITERATURE REVIEW}

Theory of Reasoned Action (TRA)

Theory of Reasoned Action is a model for the prediction of behavioral intention, spanning predictions of attitude and predictions of behavior. The subsequent separation of behavioral intention from behavior allows for an explanation of limiting factors on attitudinal influence (Ajzen, 1980). Fishbein in 1975 and Ajzen developed this model in 1980 that led to the study of attitudes and behaviors. The belief about the result behavior and the evaluation of the result will shape the attitude. This research applied the TRA model to investigate the process that leads to the decision of why the recipient pays back the loan. This will later lead to the actual behavior of repayment of the loan depending on the degree of the student's evaluation that perceives it as negative or positive. Attitude of repayment and parental influence can be measure by a likert scale. When the outcome of the two variables are positive, the intention of doing the repayment will shape. Figure 3.0 shows the theoretical framework based on theory of reasoned action used as the basis of this research.

\section{Theoretical Framework}

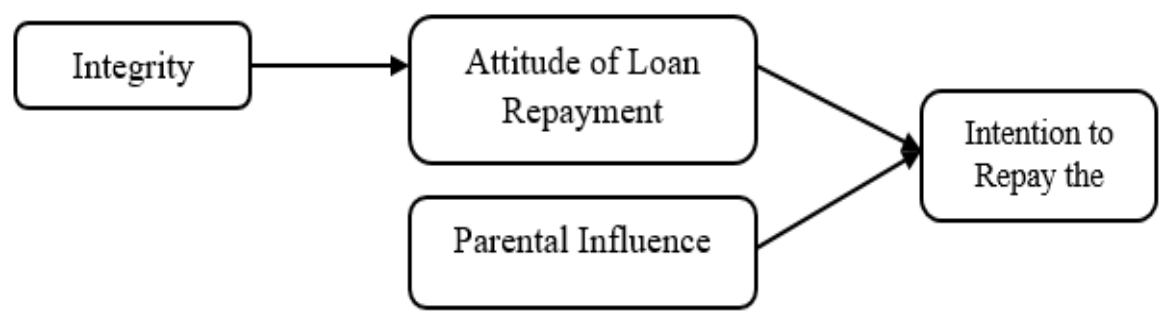

Figure 3: Theoretical Framework

\section{Integrity}

People usually describe an integrity as doing right thing even nobody else is around. Integrity can be defined as an ability to act with honesty and be consistent in whatever it is one is doing based on the particular moral, value or belief compass the person it has (Mondal U., 2013). Deputy Higher Education (2016), Minister Datuk Mary Yap Kain Ching mention that Students who have completed their studies should have the integrity and honesty to repay their National Higher Education Fund Corporation (PTPTN) loans, Students cannot be ignored with their responsibility towards repayments loans because this will affect other students which applying for education loan. A study by Rosli (1998), stated that borrower's profile is important before approving for loan application in order to evaluate the integrity and selfattitude of the borrower. An honest and good integrity borrower would have the awareness to fulfill their responsibility. Thus, it is hypothesized that:

H1: The higher the integrity, the higher the attitude towards loan repayment

\section{Attitude of Loan Repayment}

The selfish attitude is the best word to describe the borrowers who do not pay back the educational loan provided by the government agency. Among the bad attitudes by the borrowers are: (1) the practice of friends that influence the borrowers for not paying the loan; (2) subsidy mentality; and (3) dishonest and irresponsible. The attitude practiced by the seniors also influenced them. They become braver to turn into irresponsible borrowers by following the footstep of their friends. Even though they have planned to pay back the loan, but they are not serious about it since they knew that the loan that they are borrowing does not charge any interest. Moreover, they thought that the duty of the agency is more towards charity ship rather than burdening them. The subsidy mentality should also be shredded out of their mind instead, they should thank the government agency for providing such facility to them until they could get a good job with a better income. Some of them put higher priority to other loans such as a car, housing or computer loan than their study loans obtained from the government agency. 
Weak linkages between attitudes and behavior are often noted in previous studies within western societies (Volkwein \& Szelest, 1995; Baum \& Schwartz, 1988) as cited in Ismail et al. (2010). A study by Abu Bakar et al. (2006) finds that overall the respondents have negative attitudes towards loans and loan repayment. Hence, the negative attitudes and perceptions may affect the repayment of the loan once they graduate.

$\mathrm{H} 2$ : There is significant relationship between attitude towards the intention to repay the loan

\section{Parental Influence}

Parental contributions were significantly influenced by family type, race, and savings patterns of parents (Dennis, 1993). Students and family should start financial aid planning six months to a year prior to requesting loan (Dennis, 1993). Parents need to decide what part of their financial contribution will come from past savings, current income, and future borrowing. The role of parents includes having a college-educated parent, as well as family income above the thresholds (Volkwein et al., 1998). In family financing of college education, parents played the ultimate role of aid administrators. Churaman (1992) reported that family financial management issues must be considered to manage the increasing cost of education. Each of the following borrower characteristics to have a statistically significant association with a lower probability of default i.e. parent's income, and the presence of two parents at home (Knapp \& Seaks, 1992).

The parents became important because there are some schemes involve means testing based on family income at the point of entry to higher education (Jackson, 2002; Ziderman, 2004), and the financial situation of the student's family (Chung, 2003), as well as loan, is guaranteed through the assets of parents/guardians (Ziderman, 2005). The influences of parents are identified to be direct or indirect (Jessor and Jessor, 1977). Usually, young people's behavior is influenced by their parents' approval (Jessor and Jessor, 1977) and their parents' knowledge of the problem at hand (Reynolds, 1980).

Evidence from other research disciplines suggests that parents can have a positive impact on the development of their children's personalities, including attitude (Vandell, 2002). Parents influence their children directly, through discussions and training (Ward et al., 1977). Young people who talk to their parents regularly about positive habits are more likely to behave positively than young people whose parents do not talk to them regularly (Grolnick and Slowiaczek, 2008). Some empirical work has, however, suggested that the size of any parental contribution is closely associated with social class (Callendar and Kemp, 2000).

H3: There is significant relationship between parental influence towards the intention to repay the loan.

\section{METHODOLOGY}

\section{Unit of Analysis}

The unit of analysis of this study is individual. Therefore, the alumni of state foundation borrower are used for respondent or unit analysis for this study. Both current and past borrowers are considered for this study. The list of recipients is prepared by the state foundation from disbursement unit.

\section{Population and Sampling}

A population refers to the entire group of people, events or topics of interest that the researcher wishes to investigate (Sekaran \& Bougie, 2010). The population of this study is State Foundation borrowers. The importance of the sample study has been highlighted by (Hair, Hult, Ringle, \& Sarstedt, 2017). Sampling technique is important because it affects the further analysis of statistical reliability and its appropriateness.

As this study population is State Foundation and there is a limited number of students available to meet the sampling requirement, a minimum sampling calculation is needed. Therefore, this study will follow Roscoe (1975) recommendation for minimum sample size if statistical analysis can be done. This study minimum sample size is 20 and not more than 500 (Hair et al., 1998). Since there are 4 variables, according to roscoe's rule of thumb there should be 40 sample size.

\section{Data Collection Method}

The period for data collection was three months, due to small sample size, this study has taken measures to increase the response rate by reminding respondent to answer the questionnaire two weeks after the sending the survey. The questionnaire was sent to the by using e-mail About 200 questionnaires were distributed to the respondent because according to social science research $20 \%$ of response rate able to yield more accurate result (Visser et al., 1996). From the sample, only 48 questionnaires can be used. The development of the questionniare was measured by variables as shown in Table 1. 
Table 1: Variable Measurements

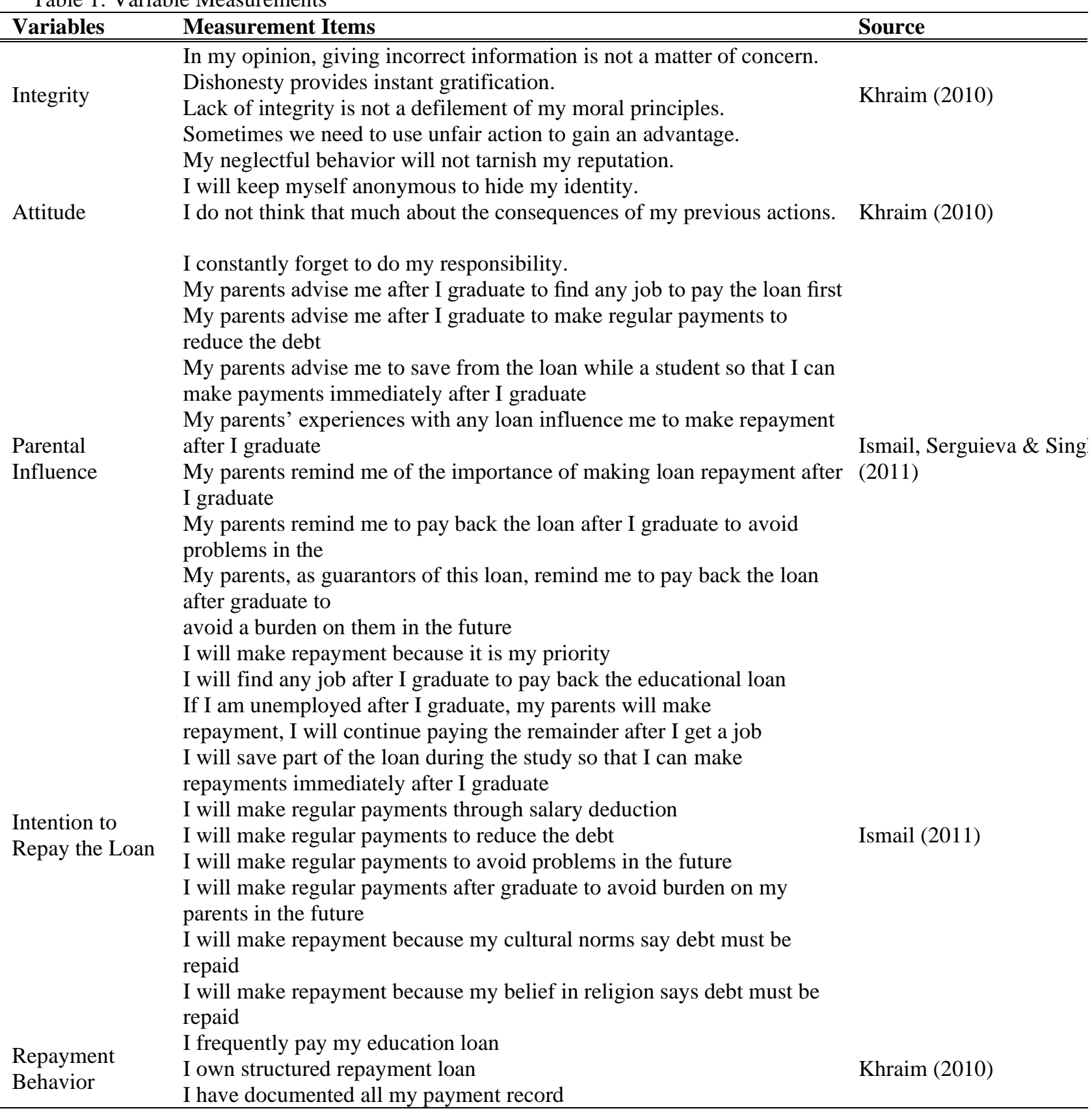

\section{FINDINGS}

\section{Demographic Analysis}

Table 2 shows the respondents' profile that asked about the respondents' loan repayment status, gender, age, ethnicity, highest education level, and program. About 8 respondents which are $16.67 \%$ of them just finished the study and wanted to start the loan repayment, 21 respondents $(43.75 \%)$ have identified as loan recipients which are currently active paying. Out of 19 respondents have already finished their studies but unable to pay back a loan. There are 48 respondents ( $70.8 \%$ ) who are female and $29 \%$ are male. Majority of respondents in this study are in the age range of 20 - 30 years' old which counts of 40 people (83.33\%). $4.17 \%$ of respondents are in the age range of 41 - 50 years old. In term of ethnicity, Malay contributed to the highest number of loan recipients $(83.33 \%)$ while Chinese and Indian are equally consisting of 2 respondents $(4.17 \%)$. In term of education, the majority of respondents have a degree $(45.83 \%)$ and the least number of respondents are certificate loan recipient $(6.25 \%)$. 
Table 2: Profile of Respondents

\begin{tabular}{|c|c|c|c|}
\hline Demographic & Characteristics & Frequency $(\mathbf{N})$ & Percentage (\%) \\
\hline \multirow{3}{*}{ Loan Recipient Status } & $\begin{array}{l}\text { Just finished the study and wanted to start payback } \\
\text { loan }\end{array}$ & 8 & 16.67 \\
\hline & Currently an active payer & 21 & 43.75 \\
\hline & $\begin{array}{l}\text { Already finished study but unable to pay back the } \\
\text { loan, thus seeking for a consultation session with YP }\end{array}$ & 19 & 39.58 \\
\hline \multirow{3}{*}{ Gender } & Female & 34 & 70.83 \\
\hline & Male & 14 & 29.16 \\
\hline & 20 - 30 years old & 40 & 83.33 \\
\hline \multirow{3}{*}{ Age } & $31-40$ years old & 6 & 12.5 \\
\hline & $41-50$ years old & 2 & 4.17 \\
\hline & 51 years old and above & 0 & 0 \\
\hline \multirow{4}{*}{ Ethnicity } & Malay & 44 & 91.67 \\
\hline & Chinese & 2 & 4.17 \\
\hline & India & 2 & 4.17 \\
\hline & Others & 0 & 0 \\
\hline \multirow{7}{*}{ Highest Education } & Certificate / Competency & 19 & 39.58 \\
\hline & Diploma & 0 & 0 \\
\hline & Advanced Diploma & 0 & 0 \\
\hline & Pre-Degree / Foundation & 0 & 0 \\
\hline & Degree & 22 & 45.83 \\
\hline & Master & 7 & 14.5 \\
\hline & Doctorate & 0 & 0 \\
\hline \multirow{13}{*}{ Program } & Accounting & 4 & 8.3 \\
\hline & Art & 3 & 6.2 \\
\hline & Business & 3 & 6.2 \\
\hline & Engineering & 9 & 18.7 \\
\hline & Education & 0 & 0 \\
\hline & Islamic Studies & 13 & 27 \\
\hline & Information Technology & 7 & 14.5 \\
\hline & Law & 0 & 0 \\
\hline & Science & 2 & 4.1 \\
\hline & Medical/ Health & 2 & 4.1 \\
\hline & Law & 0 & 0 \\
\hline & Pilot & 2 & 4.1 \\
\hline & Other & 3 & 6.2 \\
\hline
\end{tabular}

\section{Convergent Validity Analysis}

Table 3 shows the results of convergent validity of the measurement model with 26 measurement items in the model. The convergent validity is measured by examining the factor loadings, Average Variance Extracted (AVE) and composite Reliability (CR) (Fernando \& Wah, 2017; Rahman et al., 2015). An acceptable value for loadings should be at least 0.5 to be significant (Hair et al., 2017). In this study, all loadings are above 0.5 thresholds. AVE of the model was viewed to be within the range of 0.585 to 0.916 . CR, on the other hand, portrays the degree to which the construct indicators indicate the latent and the recommend accepted value above 0.07 (Hair et al., 2009). From table 3, the CR was at the range 0.874 to 0.972 . Rho_A results are indicated exceed the 0.70 of cut-off value (Dijkstra \& Henseler, 2015). Based on the results, the constructs measurements are valid and reliable. Figure 4 is the convergent validity result with PLS SEM. This study follows methodology reporting of Fernando, Shaharudin, Ismail, Yew, and Ganesan (2018). 


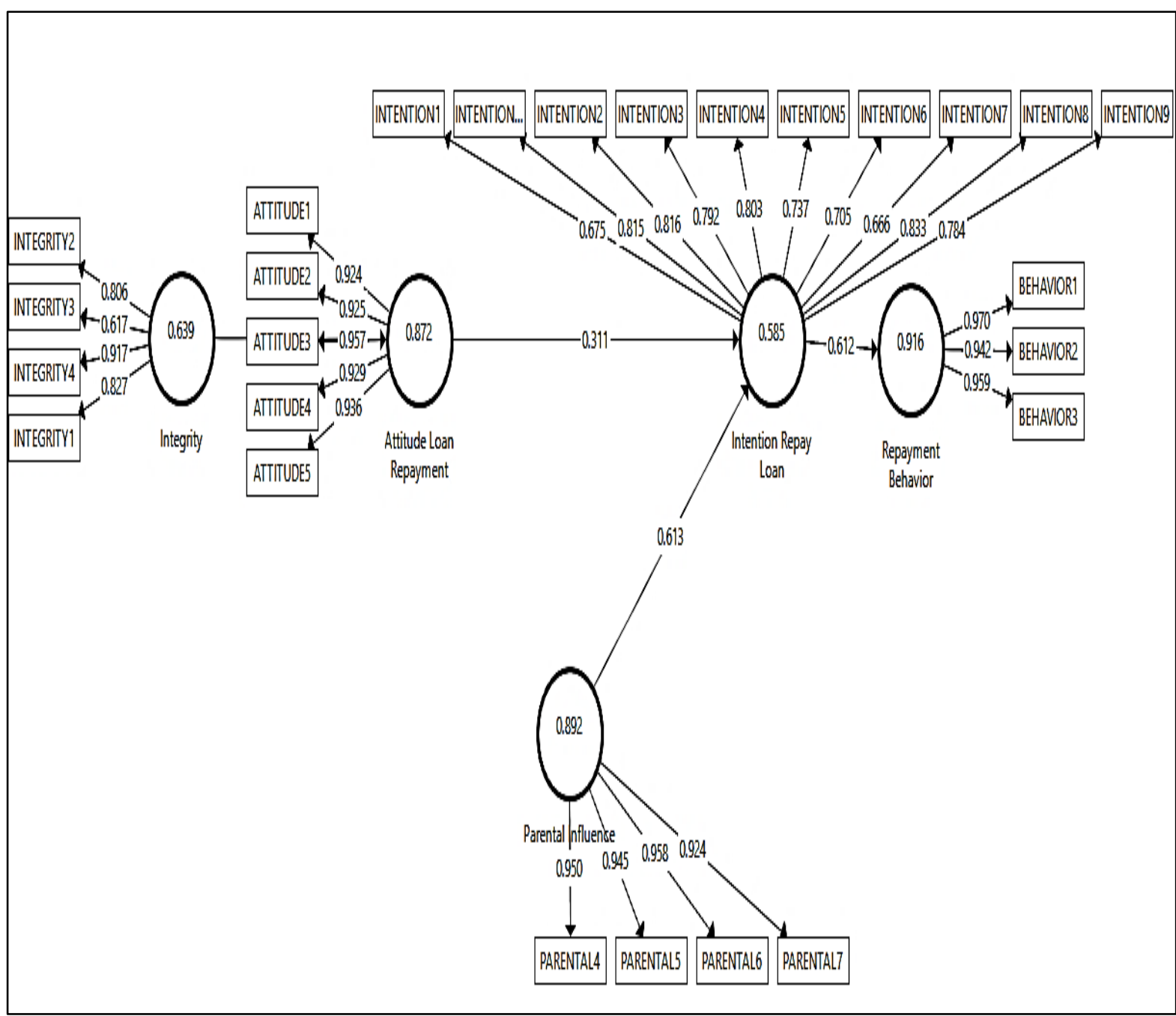

Figure 4. Convergent Validity with PLS SEM

Table 3. Result of Measurement Model of VB-SEM using SmartPLS

\begin{tabular}{|c|c|c|c|c|c|}
\hline Construct & Items & Loadings & $\mathbf{C R}$ & AVE & $\mathbf{r}^{2}$ \\
\hline \multirow{5}{*}{ Attitude of Loan Repayment } & Attitude1 & 0.924 & \multirow{5}{*}{0.972} & \multirow{5}{*}{0.872} & \multirow{5}{*}{0.457} \\
\hline & Attitude2 & 0.925 & & & \\
\hline & Attitude3 & 0.957 & & & \\
\hline & Attitude4 & 0.929 & & & \\
\hline & Attitude5 & 0.936 & & & \\
\hline \multirow{3}{*}{ Repayment Behavior } & Behavior1 & 0.97 & \multirow{3}{*}{0.97} & \multirow{3}{*}{0.916} & \multirow{3}{*}{0.375} \\
\hline & Behavior2 & 0.942 & & & \\
\hline & Behavior3 & 0.959 & & & \\
\hline \multirow{4}{*}{ Integrity } & Integrity 1 & 0.827 & \multirow{4}{*}{0.874} & \multirow{4}{*}{0.639} & \multirow{12}{*}{0.655} \\
\hline & Integrity 2 & 0.806 & & & \\
\hline & Integrity3 & 0.617 & & & \\
\hline & Integrity4 & 0.917 & & & \\
\hline \multirow{8}{*}{ Intention to Repay Loan } & Intention1 & 0.675 & \multirow{8}{*}{0.933} & \multirow{8}{*}{0.585} & \\
\hline & Intention 10 & 0.815 & & & \\
\hline & Intention2 & 0.816 & & & \\
\hline & Intention3 & 0.792 & & & \\
\hline & Intention4 & 0.803 & & & \\
\hline & Intention5 & 0.737 & & & \\
\hline & Intention6 & 0.705 & & & \\
\hline & Intention7 & 0.666 & & & \\
\hline
\end{tabular}




\begin{tabular}{|c|c|c|c|c|c|}
\hline Construct & Items & Loadings & $\mathbf{C R}$ & AVE & $\mathbf{r}^{2}$ \\
\hline \multirow{6}{*}{ Parental Influence } & Intention8 & 0.833 & \multirow{6}{*}{0.971} & \multirow{6}{*}{0.892} & \\
\hline & Intention9 & 0.784 & & & \\
\hline & Parental4 & 0.95 & & & \\
\hline & Parental5 & 0.945 & & & \\
\hline & Parental6 & 0.958 & & & \\
\hline & Parental7 & 0.924 & & & \\
\hline
\end{tabular}

*Parental 1, Parental 2, Parental 3 were deleted because loading <0.5

\section{Hypothesis Testing Analysis}

In order to test the hypothesis testing, path analysis was used. The hypothesis was develop containing of 4 hypotheses in this study. For hypothesis testing purpose, parameter estimates and coefficient values were used to generate the estimated population covariance matrix for the model (Tabacnick \& Fidell, 2011). The result of the hypothesis testing using PLS analysis shows that all the hypotheses have a significant relationship (t-value: >1.645).

Table 4 shows that all the hypothesis have a significant relationship towards intention to repay the loan and repayment behavior which all the $p$ value $<0.005$. while for the Std Beta value is ( $\beta=0.311$ for attitude), $(\beta=0.676$ for integrity), ( $\beta=0.612$ for parental influence) and ( $\beta=0.613$ for intention). In fact, among all those hypotheses, the link between integrity towards attitude have the strongest relationship. This result proves the theory of reason action (TRA) explained well on the attitude and norms towards the intention.

Table 4. Hypothesis Testing

\begin{tabular}{llcccc}
\hline Hypothesis & Std Beta & t-value & p value & Decision \\
\hline \hline $\mathrm{H}_{1}$ & Attitude Loan Repayment -> Intention Repay Loan & 0.311 & 3.394 & $\mathrm{p}<0.001$ & Accept \\
$\mathrm{H}_{2}$ & Integrity -> Attitude Loan Repayment & 0.676 & 11.906 & $\mathrm{p}<0.001$ & Accept \\
$\mathrm{H}_{3}$ & Parental Influence -> Intention Repay Loan & 0.612 & 6.349 & $\mathrm{p}<0.001$ & Accept \\
\hline
\end{tabular}

\section{DISCUSSION AND RECOMENDATION}

This study used integrity, attitude and parental influence to measure loan recipient intention. Based on the findings, the determinant (integrity) have a positive relationship towards the attitude of the recipient. Other than that, the result found that attitude towards loan repayment have a significant impact to the intention to repay the loan. In other word, when there are good factors can influence a person to do something, it will turn out into a good attitude and vice versa. Thus, it is clearly showing that if attitude can be changed, intention may be influenced subsequently (Al-Rafee and Cronan, 2006). Other than that, the result showed parental influence affect the intention to do the loan repayment. As what been said by Wackman et al., (1997), parents play important role to influence children directly, through discussion and training. Overall, the higher the of the integrity, the higher the attiude of the recipient to pay back the loan which will lead to the positive significant relationship towards the intention to repay the loan.

\section{Limitation \& Suggestion for Future Research}

Although the research has reached its objectives, there is an unavoidable constrains which is the slow network (internet connection). Because of the questionnaire is given throughout the email. Some of the respondents are not able to answer the questionnaire due to the limited internet connection in their area. Thus, this will affect their emotion to answer the question when the connection is distrusted for example the page is keep reloading when respondent want to proceed to the next page. Therefore, it tends to get bias results. Since the limitation of this study is limited internet connection, future researcher can do for both methods to collect the data which is distributing the questionnaire physically and also using email. So that the researcher can collect more number of respondent.

\section{Recommendation}

Based on the result, attitude and parental influence are played important role in collecting back the loan from the recipient. Therefore, this study can help the collection unit in state foundation to increase the awareness by focusing more to the parents by to providing more program with them which could help the state foundation to attract the recipient. Besides, the disbursement unit may give a test/ interview to the recipient in order to identify their characteristic especially their level of integrity before they can proceed to the next process of application. 


\section{CONCLUSION}

Overall, the study has achieved its objective and has found that loan recipient with a good integrity attitude had an intention to pay back the loan. Other than that, parental influence has found a positive affect to influence the loan recipient to pay back their loan. Therefore, the state foundation can take a make an improvement by looking the recipient attitude as early in the stage of approving the loan so that, they have the ability and the willingness to do the loan repayment. Also, this state foundation should constantly remind the loan recipient together with their guardian about their responsibility to pay back a loan.

\section{ACKNOWLEDGMENT}

Our thanks to staffs of State Foundation who have kindly provided us assistance and support in particular have given us access to a lot of valuable information. Last but not least, we would like to thank those who have participated in this study, without their time and cooperation, the study would not have been completed

\section{REFERENCES}

Caccese, J. B., Buckley, T. A., Tierney, R. T., Arbogast, K. B., Rose, W. C., Glutting, J. J., \& Kaminski, T. W. (2018). Head and neck size and neck strength predict linear and rotational acceleration during purposeful soccer heading. Sports Biomechanics, 17(4), 462-476. https://doi.org/10.1080/14763141.2017.1360385

Huang, X., Sun, J., \& Sun, J. (2018). Albrecht, D. \& Ziderman, A. (1992). Student Loans and Their Alternatives: Improving the Performance of Deferred Payment Programs. Journal of Higher Education. 23: 357-374

Al-Rafee, S., \& Cronan, T. P. (2006). Digital Piracy: Factors that Influence Attitude Toward Behavior. Journal of Business Ethics, 63(3), 237-259.

Ajzen, I. (1985). From intentions to actions: A theory of planned behavior. Action control (pp. 11-39). Springer Berlin Heidelberg.

Ajzen, I. (2006). Constructing a TPB Questionnaire: Conceptual and Methodological Considerations. Retrieved June 27, 2011, from the World Wide Web: http://www.people.umass.edu/aizen/pdf/tpb.measurement.pdf.

Abu Bakar, E., Masud, J. \& Jusoh, M.Z. (2006), "Knowledge, attitude and perceptions of university students towards educational loans in Malaysia", Journal of Family Economics Issue, Vol. 27, pp. 692-701.

Barone, S. (2006). Multivariate analysis of student loan defaulters at Prairie View A\&M University. Round Rock, TX: Texas Guaranteed student loan Corporation

Baum, S. \& Schwartz, S. (1988), The Impact of Student Loans on Borrowers: Consumption Patterns and Attitudes Toward Repayment, Tufts University, Boston, MA.

Christman, D. E. (2000). Multiple realities: Characteristics of loan defaulters at a two-year public institution. Community college review, 27(4), 16-32.

Dabholkar, P.A., D.I. Thorpe \& J.O. Rentz (1996). "A measure of service quality for retail stores: Scale development and validation," Journal of the Academy of Marketing Science, 24 (1), 3-16.

Dillon, E. \& Smiles, R.V. (2010), Lowering student loan default rates: what one consortium of historically black institutions did to succeed, Education Sector.

Fernando, Y., \& Wah, W. X. (2017). The impact of eco-innovation drivers on environmental performance: Empirical results from the green technology sector in Malaysia. Sustainable Production and Consumption, 12, 27-43.

Fernando, Y., Shaharudin, M. S., Ismail, I., Yew, S. Q., \& Ganesan, Y. (2018). A Mediating Model of Resource Commitment, Reverse Logistics and Financial Performance: Importance-Performance Map Analysis. In 8th International Borneo Business Conference (pp. 20-30). Kuching, Sarawak.

Flint, T. (1997). Predicting student loan defaults. The Journal of Higher Education, 68, 322-354. http://dx.doi.org/10.2307/2960044

Groves, M. (1992). Managing Problem Loans. Illinois: Bank Administration Institute, Toppan Co, Limited.

Grolnick, W.S. \& Slowiaczek, M.L. (1994), "Parents' involvement in children's schooling: a multidimensional conceptualization and motivational model”, Child Development, Vol. 65 No. 1, pp. 237-52.

Harrast, S. A. (2004). Undergraduate borrowing: A study of debtor students and their ability to retire undergraduate loans. Journal of Student Financial Aid, 36(1), 34-52.

Hakwan, C.L., Robert, D.R., Patrick, H. \& Richard, E.P. (2004), “Attention to intention”, Science, Vol. 303 No. 5661, pp. 1208-10.

Herr, E., \& Burt, L. (2005). Predicting student loan default for the University of Texas at Austin. Journal of Student Financial Aid, $35(2), 27-49$.

Hira, T.K., Anderson, M.M. \& Petersen, K. (2000), "Students' perceptions of their education debt and its impact on life after graduation", Journal of Student Financial Aid, Vol. 30, pp. 7-19.

Hossler, D., Gross, J., Osman, C., \& Hillman, C. (2008). A review of the literature: What matters to student loan default. Retrieved from http://www.nasfaa.org/workArea/linkit.aspx?LinkIdentifier=id

Hunt, H. K. (1977). CS/DB overview and future research direction. In H. K. Hunt (Ed.), Conceptualization and measurement of consumer satisfaction and dissatisfaction (pp. 455e488). Cambridge, MA: Marketing Science Institute.

Ismail, M., Khalid, S.A., Othman, M., Jusoff, K., Abdul Rahman, N., Mohamed Kassim, K. \& Shekh Zain, R. (2010), Entrepreneurial Intention among Malaysian Undergraduates, International Journal of Business and Management, 4(10): 54-60.

Kinsler, J., \& Pavan, R. (2011). Family income and higher education choices: The importance of accounting for college quality. Journal of human capital, 5(4).

Koenig, H.G., McCullough, M. \& Larson, D.B. (2000), Handbook of Religion and Health, Oxford University Press, New York, NY.

Manstead, A. S. R., Proffitt, C., \& Smart, J. L. (1983). Predicting and understanding mothers' infant-feeding intentions and behavior: Testing the theory of reasoned action. Journal of Personality and Social Psychology, 44, 657-671

Migali, G. (2006). Funding higher education and wage uncertainty: Income contingent loan versus Mortgage Loan. Warwick Economics Research Paper Series N. 740.

Mondal, U. (2013). Integrity, competency and ethical behaviour. International Journal of Marketing and Technology, 3(4), 188. 
Montoya-Weiss, M.M., G.B. Voss \& D. Grewal (2003). "Determinants of online channel use and overall satisfaction with a relational multichannel service provider," Journal of the Academy of Marketing Science, 31 (4), 448-458.

Patricio, L., R.P. Fisk \& J. Falcao e Cunha (2003). "Improving satisfaction with bank service offerings: Measuring the contribution of each delivery channel," Managing Service Quality, 13 (6), 471-482.

Podgursky, M., Ehlert, M., Monroe, R., Watson, D., \& Wittstruck, J. (2002). Student loan defaults and enrollment persistence. Journal of Student Financial Aid, 32(3), 27-42.

Rosli Mahmood (1998). Perbankan dan Pemberian Pinjaman. Kuala Lumpur: Utusan Publications \& Distributors Sdn. Bhd.

Shouxin, L. \& Bray, M. (1992). Attempting a Capitalist Form of Financing in A Socialist System: Student Loans in the People's Republic of China. Journal of Higher Education. 23: 375-367.

Sarah, S., Rich, W., (2010). The U.S. Is Facing a Student Loan Repayment Crisis. Retrieved from https://www.pewtrusts.org/en/research-and-analysis/articles/2018/10/09/the-us-is-facing-a-student-loan-repayment-crisis

Sarver, V. T., Jr. (1983). Ajzen and Fishbein's "theory of reasoned action": A critical assessment. Journal for the Theory of Social Behavior, 13, 155-163

Sheppard, B. H., Hartwick, J., \& Warshaw, P. R. (1988). The theory of reasoned action: A meta-analysis of past research with recommendations for modifications and future research. Journal of Consumer Research, 15, 325-343.

Spreng, R.A. \& Mackoy, R.D. (1996), "An emprical examination of a model of perceived service quality and satisfaction". Journal of Retailing, Vol.72, pp. 201-14

Van Birgelen, M., K. De Ruyter, A. De Jong \& M. Wetzels (2002). "Customer evaluations of after-sales service contact modes: An empirical analysis of national culture's consequences," International Journal of Research in Marketing, 19, 43-64.

Visser, P. S., Krosnick, J. A., Marquette, J., \& Curtin, M. (1996). Mail surveys for election forecasting? An evaluation of the Columbus Dispatch poll. Public Opinion Quarterly, 60(2), 181-227.

Volkwein, J.F. \& Szelest, B.P. (1995), "Individual and campus characteristics associated with student loan default", Research in Higher Education, Vol. 36 No. 1, pp. 41-72.

Wackman, D. B., Ward, S., \& Wartella, E. (1977). How Children Learn to Buy: The Development of Consumer Information Processing.Wilms, W. W., Moore, R. \& Bolus, R. E. (1987). Whose Fault is Default? A Study of the Impact Student Characteristics and Institutional Practices on Guaranteed Student Loan Default Rates in California. Educational Evaluation and Policy Analysis Journal. 9(1): 41-54.

Woodhall, M. (1992). Student Loans in Developing Countries: Feasibly, Experience and Prospects for Reform. Journal of Higher Education. 23: 347-356

Wu, H. C., Cheng, C. C. \& Ai, C. H. (2018). A study of experiential quality, experiential value, trust, corporate reputation, experiential satisfaction and behavioral intentions for cruise tourists: The case of Hong Kong, Tourism Management, 66, 200-220.A carfollowing model considering asymmetric driving behavior based on long short-term memory neural networks. Transportation Research Part C: Emerging Technologies, 95(February), 346-362. https://doi.org/10.1016/j.trc.2018.07.022

James, S. L., Abate, D., Abate, K. H., Abay, S. M., Abbafati, C., Abbasi, N., Abbastabar, H., Abd-Allah, F., Abdela, J., Abdelalim, A., Abdollahpour, I., Abdulkader, R. S., Abebe, Z., Abera, S. F., Abil, O. Z., Abraha, H. N., Abu-Raddad, L. J., Abu-Rmeileh, N. M. E., Accrombessi, M. M. K., ... Murray, C. J. L. (2018). Global, regional, and national incidence, prevalence, and years lived with disability for 354 diseases and injuries for 195 countries and territories, 1990-2017: a systematic analysis for the Global Burden of Disease Study 2017. The Lancet, 392(10159), 1789-1858. https://doi.org/10.1016/S0140-6736(18)32279-7

Tan, H., Qin, L., Jiang, Z., Wu, Y., \& Ran, B. (2018). A hybrid deep learning based traffic flow prediction method and its understanding. Transportation Research Part C: Emerging Technologies, 90(January), 166-180. https://doi.org/10.1016/j.trc.2018.03.001

Taylor, K., Post, A., Hoshizaki, T. B., \& Gilchrist, M. D. (2019). The effect of a novel impact management strategy on maximum principal strain for reconstructions of American football concussive events. Proceedings of the Institution of Mechanical Engineers, Part P: Journal of Sports Engineering and Technology, 233(4), 503-513. https://doi.org/10.1177/1754337119857434 